\title{
Teaching neonatal circumcision
}

\section{Peter Metcalfe, MD, FRCSC}

Division of Urology, University of Alberta, Edmonton, AB
See related article on page 260 .

Cite as: Can Urol Assoc J 2013;7(7-8):265. http://dx.doi.org/10.5489/cuaj.1523 Published online August 19, 2013.

1 would like to thank the authors for a relevant and thought provoking article. ${ }^{1}$ The American Association of Pediatrics (and pending Canadian Pediatric Society) has just revised their policy statement, and now states that there may be a potential medical benefit to routine neonatal circumcision. ${ }^{2}$ Therefore, the numbers of neonatal circumcisions performed may soon increase. However, very few urologists in Canada perform neonatal circumcisions, ${ }^{3}$ as the majority are performed by family physicians, pediatricians and obstetricians. Furthermore, most of these primary care physicians have not trained by urologists or had any formal training.

DeMaria and colleagues highlight this discrepancy well, with most circumcisions performed by non-urologists and accordingly, most of these primary care physicians have not been trained by urologists. In this era of structured training and formal assessments, I believe we need to ensure that all anon-urologists who perform urologic procedures have a fundamental understanding of the procedure.

Although not a technically demanding procedure, neonatal circumcisions still incur complications and they can be significant. ${ }^{3-6}$ There have been several recent publications highlighting the need for adequate training with the goal of minimizing the risk of complications. ${ }^{7-10}$ As with any procedure, the best way to avoid complications is to recognize and avoid abnormal anatomy and contraindications. ${ }^{6,11}$ The authors should be applauded for developing and instituting an effective course aimed at reducing complications.

Their survey would indicate the course was well-received and appreciated by the trainees. Hopefully, this will translate into fewer complications and better outcomes. The authors also provide a link to a couple of very well done videos. The first video demonstrates surgical technique for a GOMCO clamp, but the second provides some excellent teaching regarding anatomical variations not appropriate for a circumcision, and basic management of common complications.

The manuscript does not outline plans for further CME courses or how the authors plan to promote their website. Both are likely to greatly benefit practitioners.

Competing interests: None declared.

\section{References}

1. DeMaria J, Abdulla A, Pemberton J, et al. Are physicians performing neonatal circumcisions well-trained? Can Urol Assoc J 2013;7:260-4. htrp://dx.doi.org/10.5489/cuaj.200

2. Metcalfe PD, Elyas R. Foreskin management: Survey of Canadian pediatric urologists. Can Fam Physician 2010;56:e290-5.

3. Pieretti RV, Goldstein AM, Pieretti-Vanmarcke R. Late complications of newborn circumcision: a common and avoidable problem. Pediatr Surg Int 2010;26:515-8. http://dx.doi.org/10.1007/s00383-010-2566-9

4. Zhang $H$, Xiong $E Q$, Liu $L M$, et al. Penile necrosis after circumcision owing to inappropriate postoperative treatment. J Pediatr Surg 2011;46:1469-70. http://dx.doi.org/10.1016/i.jpedsurg.2011.03.006

5. Canter HI, Coskuner ER. Penile necrosis due to priapism developed after circumcision in a patient with protein S deficiency. J Sex Med 2011;8:3236-40. http://dx.doi.org/10.1111/i.1743-6109.2011.02415.x

6. Krill AJ, Palmer LS, Palmer JS. Complications of circumcision. ScientificWorldJournal 201 1;11:2458-68. http://dx.doi.org/10.1100/2011/373829

7. Ekenze SO, Ezomike UO. Complications of Neonatal Circumcision Requiring Surgical Intervention in a Developing Country. J Trop Pediatr 2013;59:292-7. http://dx.doi.org/10.1093/tropej/fmt020

8. Mayer E, Caruso DJ, Ankem M, et al. Anatomic variants associated with newborn circumcision complications. Can J Urol 2003;10:2013-6.

9. Soper RJ, Brooks G, Fletcher K, et al. A training model for circumcision of the newborn. Clin Pediatr (Phila) 2001;40:409-12. http://dx.doi.org/10.1177/000992280104000709

10. Le B, Sharma V, Kim D, et al. Routine neonatal cir cumcision: Opportunities for improving residency training. J Pediatr Urol 2012. http://dx.doi.org/10.1016/i.jpurol.2012.05.012

11. Alter GJ, Horton CE, Horton CE, Jr. Buried penis as a contraindication for circumcision. J Am Coll Surg 1994; 178:487-90.

Correspondence: Dr. Peter Metcalfe, Division of Urology, University of Alberta, Suite 400 Hys Centre, 11010-101 St., Edmonton, AB T5H 4B9; pmetcalf@ualberta.ca 